\title{
Correction to: Assessment by Comparative Judgement: An Application to Secondary Statistics and English in New Zealand
}

Neil Marshall $^{1} \cdot$ Kirsten Shaw $^{1} \cdot$ Jodie Hunter $^{2} \cdot$ Ian Jones $^{3}$

Published online: 7 May 2020

(c) New Zealand Association for Research in Education 2020

\section{Correction to: New Zealand Journal of Educational Studies https://doi.org/10.1007/s40841-020-00163-3}

This correction has been initiated as incorrect version of the article and vendor overlooking several errors was published.

The original article has been thus updated with the correct version.

Publisher's Note Springer Nature remains neutral with regard to jurisdictional claims in published maps and institutional affiliations.

The original article can be found online at https://doi.org/10.1007/s40841-020-00163-3.

Ian Jones

I.Jones@lboro.ac.uk

1 New Zealand Qualifications Authority, Wellington, New Zealand

2 Institute of Education, Massey University, Wellington, New Zealand

3 Mathematics Education Centre, Loughborough University, Loughborough, UK 